\title{
DISTRIBUTION OF RABIES THAT INFECT HUMAN IN INDONESIA DURING ONE LAST DECADE
}

\author{
Putri Reno Intan ${ }^{1}$, Zainal Khoirudin ${ }^{2}$, Khariri ${ }^{1}$ \\ ${ }^{1}$ Center for Research and Development of Biomedical and Basic Health Technology \\ ${ }^{2}$ Directorate of Prevention and Control of Vector Borne and Zoonotic Diseases, Jakarta, Indonesia. \\ ${ }^{1}$ putrirenointan111@gmail.com, ${ }^{2}$ drhzainalkhoirudin@yahoo.com, ${ }^{3}$ arie.tegale@ gmail.com
}

\begin{abstract}
Rabies is a zoonosis that attacks the central nervous system with the ultimate goal of the central nervous system, brain and spinal cord of warm-blooded animals and humans. The rabies virus is secreted with the saliva of infected animals and is transmitted through bites or licks on the skin injured by Animal Transmission Rabies (HPR), especially dogs, cats and monkeys. This article is a literature review of the threat of distribution of rabies that infect humans in indonesia at one last decade. Data collection is carried out through library research from reports of rabies cases during one last decade. Around the world, every year an estimated 24,000 people are bitten by dogs and other animals suffering from rabies. The first rabies case in Indonesia occurred in 1884. Reports of rabies cases in the last decade are still fluctuating. The average number of bite cases of rabies-carrying animals (GHPR) every year in humans in the past one decade has been reported as many as 66,939 cases, and 50,065 cases $(74.79 \%$ ) of which get Anti-Rabies Vaccine (VAR). Last report in 2019, the number of HPR bite cases was 100,826 cases and 67,625 cases (67\%) received VAR. Until 2019, rabies is spread in 26 provinces in Indonesia. Mass vaccination as a method for controlling rabies has been known since 1920. Rabies vaccination is the most effective approach in controlling rabies in both animals and humans.
\end{abstract}

Keywords: animal, rabies, human, zoonotic disease

\section{Introduction}

Rabies is an acute infectious disease of the central nervous system caused by the rabies virus belonging to the genus lyssavirus, rhabdoviridae family with the ultimate target of the central nervous system, brain and spinal cord of warm-blooded animals and humans (1). The rabies virus is released with the saliva of animals infected and transmitted through bites or licks of injured skin by rabies infectious animals (HPR), especially dogs, cats and monkeys. Other animals such as cows, buffaloes, goats, sheep, and pigs have also been reported to have contracted the rabies virus but generally do not transmit to humans $(2,3)$

Rabies is a zoonotic disease because it can be transmitted from animals to humans and can cause death in humans with a case fatality rate (CFR) of 100 percent. The early symptoms of rabies are often subtle and we sometimes mistake it for another disease. Early symptoms of rabies include fever, headache, feeling unwell, feeling afraid or anxious. In addition, about half of rabies sufferers also experience pain and tingling at the bite site. Initial symptoms will last for 2-10 days before more severe symptoms begin to develop. This usually includes aggressive behavior, hallucinations, agitation, and producing a lot of saliva $(2,4)$.

After the rabies virus enters through the bite wound, for 2 weeks the virus remains at the site of entry and its surroundings, then moves to reach the ends of the posterior nerve fibers without showing any change in function. The incubation period for rabies varies from 2 weeks to 2 years, but generally lasts 3-8 weeks. This has to do with the distance that the virus must travel before it reaches the brain. Arriving in the brain, the virus then multiplies and spreads widely in all parts of the neurons, especially having a special predilection for the cells of the limbic system, hypothalamus and brain stem. After multiplying itself in central neurons, the virus then travels peripherally to efferent nerve 
fibers and to voluntary and autonomic nerves. Thus the virus attacks almost every organ and tissue in the body, and reproduces in tissues such as the salivary glands, kidneys, and so on $(5,6)$.

Worldwide, an estimated 24,000 people are bitten by dogs and other animals with rabies each year. Humans infected with rabies always end up dying. The first rabies case in Indonesia occurred in 1884. In 1985 in Central Java and the Special Region of Yogyakarta, cases of rabies were reported which caused the death of 5 people $(7,8)$.

\section{Methods}

Analysis was carried out on data on annual reports of rabies case from the Zoonosis Program in the regions from 2010 to 2019 which were reported to the Directorate of Prevention and Control of Vector and Zoonotic Diseases in the Ministry of Health.

\section{Result}

Rabies case reports are still fluctuating. The average number of rabies-carrying animal bites (GHPR) per year in humans in the last 1 decade (2009-2018) was reported as 66,939 cases, and 50,065 cases (74.79\%) of whom received the Anti-Rabies Vaccine (VAR). The latest report in 2019, the number of HPR bite cases was 100,826 cases and 67,625 cases (67\%) received VAR. Until 2019, rabies has spread in 24 provinces in Indonesia(9-12)

North Sulawesi Province is the only province in the Hyperendemic Rabies area (Lyssa average $\geq 20$ in the last 3 years). A total of 23 provinces are Rabies Endemic areas (Lyssa average $<20$ in the last 3 years) covering: 1) North Sumatra Province; 2) Bali; 3) Maluku; 4) Aceh; 5) West Sumatra; 6) Riau; 7) Jambi; 8) South Sumatra; 9) Bengkulu; 10) Lampung; 11) Banten; 12) West Java; 13) East Nusa Tenggara; 14) Gorontalo; 15) North Kalimantan; 16) Central Sulawesi; 17) Southeast Sulawesi; 18) South Sulawesi; 19) West Sulawesi; 20) South Kalimantan; 21) Central Kalimantan; 22) East Kalimantan; and 23) North Maluku $(9,10,12,13)$.

Of the 34 provinces in Indonesia, ten provinces have been declared free from rabies, namely: 1. Riau Islands Province; 2. Bangka Belitung; 3. DKI Jakarta; 4. Central Java; 5. D.I. Yogyakarta; 6. East Java; 7. West Nusa Tenggara; 8. West Kalimantan; 9. Papua, and 10. West Papua.

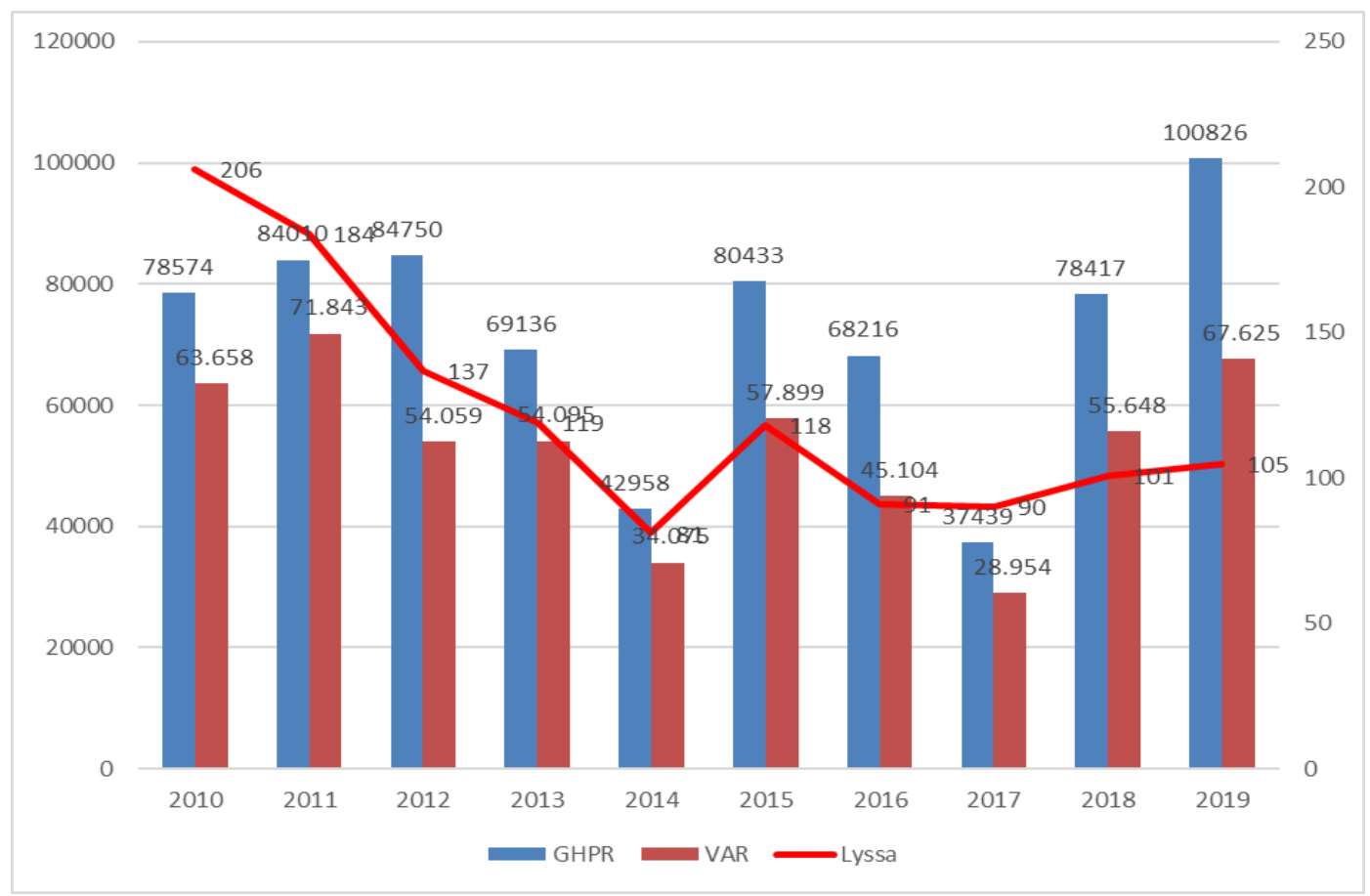

Figure 1. Distribution of rabies in the last decade in Indonesia $(9,10,12,13)$ 


\section{Discussion}

Rabies is one of the few infectious diseases that can be prevented by vaccination even after being infected with the virus. Mass vaccination as a method to control rabies has been known since the 1920's. Rabies vaccination is the most effective approach in controlling rabies in both animals and humans. Vaccination status is strongly associated with the incidence of rabies in dogs. Dogs who were not vaccinated had an almost 20 times greater risk of becoming infected with rabies than vaccinated dogs. The risk of rabies infection increased by more than 100 times in dogs that were not vaccinated. The results of this study illustrate that unvaccinated dogs are very susceptible to rabies infection, because they do not have immunity to the rabies virus $(14,15)$.

Without vaccination in dogs, in 10 years it is estimated that there will be 65,000 cases of rabies in dogs and 2100-2900 human deaths. Rabies vaccination programs in dogs can control and have the potential to eliminate rabies cases in dogs. The frequency and coverage of vaccination programs, along with the level of rabies transmission in dogs, can affect the cost effectiveness of the program activities. $(16,17)$.

Several world organizations such as the World Health Organization (WHO), Food and Agricultural Organization (FAO) and the World Organization for Animal Health (OIE) advocate a collaborative One Health approach involving public health and veterinary agencies, with mass dog vaccination programs in endemic areas for eliminating rabies in humans that is transmitted by dogs. Although post-exposure prophylaxis (PEP) is effective in preventing death in people exposed to rabies, it is relatively expensive and has little impact on the reservoir of dogs which are the main source of rabies. One Health's mass dog vaccination program has been shown to save costs in controlling rabies in endemic areas such as Tanzania and Bhutan (18).

Rabies is generally transmitted by infected animals to other animals through bites or wounds that are contaminated with the virus. As many as $99 \%$ of human deaths in the world from rabies are also related to dog bites. Susilawathi et al., (2012) reported that $92 \%$ of human victims who died from rabies were confirmed to have a history of being bitten by a dog (14). Transmission of rabies that occurs without bite wounds can occur, but the cases are very rare. Transmission through organ transplants from donors infected with the rabies virus has been reported (19-21). In addition, aerosol transmission of rabies can also occur when the concentration of the rabies virus in the air is very high, such as in laboratory workers handling the rabies virus (22).

The high number of cases of rabies transmission, either through bites or without bites, generally (71\%) occurred in Asia and in general $(76 \%)$ involved dogs, monkeys, cats and several other wild animals. Therefore minimizing the incidence of bites and exposure from animals requires certain education and concern for this disease (23).

The high and low rate of rabies cases in animals and humans in an area is influenced by the factor of public knowledge about the dangers of rabies and public awareness regarding preventive measures against rabies, both in terms of maintaining good and correct animals, namely routine vaccinations and not allowing pets to roam freely or In terms of health services after being bitten by a rabies infected animal to get appropriate treatment, the above is closely related to other factors such as: a person's age which usually correlates with the level of knowledge, formal and non-formal education, exposure to information (24).

There are several factors that affect rabies prevention efforts, such as: the presence of health workers to support and advocate for prevention through vaccination of pets by the Animal Husbandry Department, health promotion activities by Puskesmas officers, the role of family support, the community in providing information, communication and support for prevention of rabies (25).

\section{Conclusion}

Based on data from the Ministry of Health, cases of rabies transmitting animal bites (GHPR) have continued to increase since 2009 and the peak occurred in 2019 with 100,826 cases of HPR bites and 67,625 cases (67\%) receiving VAR. Positive rabies cases resulting in deaths reached its peak in 2010, at 
206 people. Although the number of deaths had decreased and reached 81 in 2014, it has again increased and in 2019 it reached 109 cases.

\section{Acknowledgements}

We would like to thank to SubDirectorate of Zoonosis, Directorate of Vector Borne and Zoonotic Diseases Prevention and Control Ministry of Health Republic of Indonesia.

\section{References}

[1] Mading M, Mau F, Penelitian L, Pengembanganpengendalian

Bersumber P, Waikabubak B. Situation of Rabies and The Effort to Tackle It in East Flores Disrict Province East Nusa Tenggara (NTT). 2004.

[2] Soeharsono. Zoonosis 2 [Internet]. 2020 [cited 2020 Sep 2]. 67-72 p. Available from:

https://books.google.co.id/books?id=R7Iq L0B1-

$\mathrm{hkC} \&$ printsec $=$ copyright $\& \mathrm{hl}=\mathrm{id} \# \mathrm{v}=$ onepa ge\&q\& $\mathrm{f}=$ false

[3] Sopi PB dan Mau F. Description of Rabies in Ende Regency, East Nusa Tenggara Province 2006-2014. Balaba [Internet]. 2015 [cited 2020 Sep 2];11 (1):43-50. Available from: https://scholar.google.co.id/scholar?hl=id \&as_sdt $=0 \% 2 \mathrm{C} 5 \& \mathrm{q}=2 . \% 09 \mathrm{Sopi}+\mathrm{PB}+\mathrm{da}$ $\mathrm{n}+\mathrm{Mau}+\mathrm{F} .+$ Gambaran+Rabies+Di+Kabu paten+Ende\%2C+Provinsi+Nusa+Tengg ara+Timur+Tahun+2006-

2014.+Balaba.+2015\%3A+11+\%281\%29 $\% 3 \mathrm{~A}+43-50 . \& b t n G=$

[4] Nugroho, Dhony Kartika, Pudjiatmoko , Diarmitha IK , Tum S SL. Rabies Surveillance Data Analysis (2008 - 2011) in Bali Province, Indonesia. Outbreak Surveilance Investig Rep. 2013;6(2):812.

[5] Rupprecht C. A tale of two worlds: public health management decisions in human rabies prevention. 2004 [cited 2020 Sep 2]; Available from: https://academic.oup.com/cid/articleabstract/39/2/281/328916

[6] Tschopp R, Bekele S, Aseffa A. Dog
Demography, Animal Bite Management and Rabies Knowledge-Attitude and Practices in the Awash Basin, Eastern Ethiopia. 2016;

[7] Brooks AGF, Carroll KC, Butel JS, Morse SA. Medical Microbiology 24 th Edition. 2007;7(3):273-5.

[8] Desato MF. Description of Rabies and Control Efforts in Ngada District, East Nusa Tenggara Province (NTT). Bull Heal Res. 2013;40(4 Des):162-70.

[9] Kemenkes RI. Indonesia's Health Profile 2016 [Internet]. Kementerian Kesehatan RI. 2017. 431 p. Available from: www.kemkes.go.id

[10] Kementerian Kesehatan Republik Indonesia. Indonesia's Health Profile 2017. 2018.

[11] Kementerian Kesehatan Republik Indonesia. Indonesia's Health Profile 2018. Kemenkes RI [Internet]. 2019. 207 p. Available from: http://www.depkes.go.id/resources/downl oad/pusdatin/profil-kesehatanindonesia/Data-dan-Informasi_ProfilKesehatan-Indonesia-2018.pdf

[12] Kementerian Kesehatan Republik Indonesia. Indonesian Health Data and Information 2019. Profil Kesehatan Indonesia. 2020;8(9):1-213.

[13] Kementerian Kesehatan Republik Indonesia. Profil Kesehatan Indonesia 2018 [Indonesia Health Statistic 2018] [Internet]. 2019. 207 p. Available from: http://www.depkes.go.id/resources/downl oad/pusdatin/profil-kesehatanindonesia/Data-dan-Informasi_ProfilKesehatan-Indonesia-2018.pdf

[14] Dibia IN, Sumiarto B, Susetya H. Risk Factors Analysis For Rabies Indogs In Bali. J Vet. 2015;16(3):389-98.

[15] Knobel DL, Lembo T, Morters M, Townsend SE, Cleaveland S, Hampson K. Dog Rabies and Its Control. In: Rabies. Elsevier Inc.; 2013. p. 591-615.

[16] Borse RH, Atkins CY, Gambhir M, Undurraga EA, Blanton JD, Kahn EB, et al. Cost-effectiveness of dog rabies vaccination programs in East Africa. Available from: https://doi.org/10.1371/journal.pntd.0006 490.t001

[17] Wallace RM, Undurraga EA, Gibson A, 
Boone J, Pieracci EG, Gamble L, et al. Estimating the effectiveness of vaccine programs in dog populations. Epidemiol Infect. 2019;147.

[18] Lavan RP, King AIMG, Sutton DJ, Tunceli K. Rationale and support for a One Health program for canine vaccination as the most cost-effective means of controlling zoonotic rabies in endemic settings [Internet]. Vol. 35, Vaccine. Elsevier Ltd; 2017 [cited 2020 Sep 2]. p. 1668-74. Available from: http://dx.doi.org/10.1016/j.vaccine.2017. 02.014

[19] Hildegund C J Ertl. Rabies and Rabies Vaccines. 2020.

[20] Vetter JM, Frisch L, Drosten C, Ross RS, Roggendorf M, Wolters B, et al. Survival After Transplantation of Corneas From a Rabies-Infected Donor. Cornea [Internet]. 2011 Feb [cited 2020 Sep 2];30(2):241-4. Available from: http://journals.lww.com/00003226201102000-00028

[21] Zhou H, Zhu W, Zeng J, He J, Liu K, Li $\mathrm{Y}$, et al. Probable rabies virus transmission through organ transplantation, China, 2015. Emerg Infect Dis [Internet]. 2016 Aug 1 [cited 2020 Sep 2];22(8):1348-52. Available from:

/pmc/articles/PMC4982156/?report=abstr act

[22] Johnson N, Fooks AR, Johnson N, Phillpotts R, Fooks AR, Fooks CAR.
Airborne transmission of lyssavirus Ethiopian Wolf Conservation Programme View project EVAg: European Virus Archive goes global View project Airborne transmission of lyssaviruses. Artic J Med Microbiol [Internet]. 2006 [cited 2020 Sep 2]; Available from: https://www.researchgate.net/publication/ 7092955

[23] Muehlenbein MP, Angelo KM, Schlagenhauf P, Chen L, Grobusch MP, Gautret $\mathrm{P}$, et al. Traveller exposures to animals: a GeoSentinel analysis. J Travel Med. 2020;

[24] Huwae LBS, Sanaky M, Pirsouw CG. Research Results Describe Knowledge, Attitudes, and Community Behavior About Rabies Prevention in Morekau Village, West Seram District, West Seram Regency, 2018 Lecturers at the Faculty of Medicine, Pattimura University, Students of the Faculty of Medicine. 2020; 2(April):47-58.

[25] Elvi Juliansyah FN. Health Service Factors, Family and Community Support with the Efforts to Prevent Rabies in the Work Area of the Pandan Community Health Center, Sungai Tebelian District, Sintang District. Visikes J Kesehat Masyarakat Publ [Internet]. 2019 [cited 2020 Sep 3];18(2, September):120-9. Available

from: http://publikasi.dinus.ac.id/index.php/visi kes 